\title{
Effect of Rural-Urban Migration on Education and Economics Development
}

\author{
Abdulraheem Mukhtar Iderawumi ${ }^{1 *}$, Iderawumi Mubarakat Abiodun ${ }^{2}$ \\ ${ }^{1}$ Department of Agricultural Science Education, The College of Education, P.M.B. 001, Lanlate, Oyo State, NIGERIA \\ ${ }^{2}$ Oyo State Universal Basic Education Board, Oyo State, NIGERIA \\ *E-mail for correspondence: m.iderawumi@gmail.com
}

No Conflict of Interest: Declared

\begin{abstract}
Over the years, demands for education have become progressively more insistent, more persuasive and complex. The kind of education given impinges on society in a variety of ways to meet an ever-widening range of needs. This research is to examine the effect of rural-urban migration on education and economic development with reference to Ibarapa East Local Government Area of Oyo State. The man and specific motives are to find out the causes of rural-urban migration how it affects the students' performance and aimed at examining its effect on productivity level of Ibarapa East Local Government Area. The instrument used for collecting the data is the questionnaire. Hypotheses were formulated, whereas simple percentage methods were used to analyze the data. The finding shows that there are the different impacts of rural-urban migration on education and development of Ibarapa East Local Government causes short fall of the labour force, short of qualified and low productivity especially in the agricultural sector. Rural-urban migration contributes to the high rate of unemployment. It increases the number of juvenile delinquencies crimes and other social vices in the society, and it has effect on the educational development of the study area. Based on all the findings, recommendation was made that the government should provide social and infrastructural facilities such as good road network, regular supply of electricity and so on for rural dwellers. And also with the various youth programs, it could be possible to reduce rural-urban migration, most especially when the young ones are exposed to sustainable livelihood activities that they could embark upon.
\end{abstract}

Keywords: Rural, Urban, Migration, Development, Economic

\section{INTRODUCTION}

Education and its provision have continually changed partners from sole colonial administration to a tripartite agency (missionary organizations, government, and private individuals). It is the primary means of the deadline with the world's major problem and challenges of a complex and rapidly changing environment in contemporary Nigeria. It pervades every field of human endeavors and plays a fundamental role in the social, political and economic development of a country. It is at these levels that knowledge to practice (Shittu, 2004). It is quite obvious that rural-urban migration is not a recent topic in the world history (Onwubiko, 2002). Every year millions of world's people make what can be tagged a momentous decision to a new abode (Abiodun, 2005). Perhaps the movement might be across two or possibly to other parts of the country. Migration has become a phenomenon among humanity since the creation of man people leave a place for another due to the difference in economics, social or political opportunity (Dwyer, 2004).

Rural-Urban migration has become worse, and an agency population is left in the country side. The tendency to dual residence, whereby villages live part of the week and the weekends in the towns, increase in magnitude. This tendency had an adverse, effect on rural enterprises. Also, it generated absentee producers who contract their enterprise on revenue sharing operations (Otite, 2004).

This situation will affect the primary production urban the same move from less favorable especially regarding socioeconomic opportunity while the people are concentrating on one particular part of society than the others. What has been the cause of low standard of education in the rural area? Why unemployment and underutilization of resources in the rural and urban center what has been the root of courses of the traffic congestion high rate of crimes 
and the increase in the population of the urban centers? Does it connote that nothing can be derived perhaps socially, economically or politically from the so-called rural areas or why are the rural areas uncared for and invariably turned to ghost town?

The study mainly examined the effects of rural-urban migration on education, economic development with reference with to Ibarapa East Local Government Area of Oyo State.

The positive and negative effects which cannot be neglected or put aside that rural-urban migration has caused the shortage of qualified teachers in the rural areas. It has also reduced the production level of the study area. Furthermore, youth unemployment is seen to be highest among secondary school leavers (NBC, 2012) with less than half being able to proceed to higher education. Similarly, there is $40 \%$ unemployment rate among urban youths aged 20-24 and 31\% among those aged 15-19 years thus leading to high rate of rural-urban migration occasioned by social vices such as youth restiveness, hooliganism, thuggery, rape, armed robbery just to mention but a few. Alhasan and Abdullahi (2013) argued that many of the Nigerian youths who drop out of 3 schools together with those who manage to complete high school lack basic skills to compete in rather a weak economy and tight labor market.

The main objective of this study is to examine the extents at which migration of people has affected the education, economic and social development of Ibarapa East Local Government Area of Oyo State.

\section{Causes of RuRal-Urban Migration}

Blair (2004) argued that "migrant workers and their families" are on the move to the cities in most parts of the world as a part of a massive international trade in manpower, the working class migrants are down to the cities with the hope tomorrow, filled with enumerative employment, better housing, education and higher living standard."

Makinwa (2002) in his view pointed out that "the overall evidence from Nigerian studies indicate economic condition as playing a decisive role in rural to urban migration. Accordingly, the result of the increasing rate of rural to urban migration is too a rapid population growth of the cities resulting in a plethora of urban problem.

White et al. (2000) maintained solidly that the normative explanation or migration is a response to economic wage rate fluctuation this, they believed that migration occurs because migrant, believed that they will be more satisfied economically and otherwise in the place that they move to than in place from which they come." Arguing strongly on the ground, Bogre and Burgess (2007) said that economic determinism is the major causes of migration to them employment opportunity is the most salient reason for rural to urban migration propelled by the need for survival therefore economic motive is the reason among the multiple causatives is the major factors of migration on any part of the world to poverty, degrading environmental condition and the lack of opportunities for personal advancement in rural area is migration to town.

\section{Materials AND Methods}

The study was carried out in Ibarapa East Local Government Area of Oyo State. The Local Government has an area of $838 \mathrm{~km}^{2}$ and a population of one hundred and eighteen thousand, two hundred and twenty-six people (National Population Commissions, NPC, 2006). The occupation of the people in the area is farming; some people engage in others like trading, teaching and civil service as well as artisan. Ibarapa East Local Government is bounded in the south by Ibarapa Central Local Government, in the west by Ibarapa North Local Government, in the East by Ido Local Government of Oyo State and Odeda Local Government, Ogun State and in the north by Iseyin Local Government. The instruments of data collection were questionnaires in which personal observation and oral interview. The random sampling method was used in selecting people both from town and villages with twenty (20) people randomly selected from ten areas of the study given the total number of two hundred respondents. The data collected were analysis, interpreted and summarized. In analyzing the data, the data collected were analyzed using frequencies count, percentages and the hypotheses were analyzed with chisquare method of data analysis.

\section{RESULTS}

The results of data from the respondents in Ibarapa East Local Government, which were analyzed to express the effects of rural-urban migration on education, social and economic development of Ibarapa East Local Government Area of Oyo State.

The chi-square method and percentage distribution methods were used to analyze the data.

\section{Hypothesis I}

$\mathrm{H}_{\mathrm{o}}$ : Poor economic opportunities and lack of infrastructural facilities in a rural area do not cause rural-urban migration.

Table 1

\begin{tabular}{|l|l|l|l|}
\hline & YES & NO & \\
\hline Male & $65(87.8 \%$ & $9(12.2 \%)$ & $74(100 \%)$ \\
\hline Female & $24(80 \%)$ & $6(20 \%)$ & $30(100 \%)$ \\
\hline Total & 89 & 15 & \\
\hline
\end{tabular}

Source: Field survey

\begin{tabular}{|l|l|l|l|l|l|}
\hline Option & Fo & Fe & Fo-Fe & $(\text { Fo-Fe })^{2}$ & $(\text { Fo-Fe })^{2} / \mathrm{Fe}$ \\
\hline Yes & 89 & 52 & 37 & 1369 & 26.3 \\
\hline No & 15 & 52 & 37 & 1369 & 26.3 \\
\hline Total & & & & & 52.6 \\
\hline
\end{tabular}

The computed $\mathrm{X}^{2}=52.6$ 
At (0.05) level significance

The $X^{2} t=3.84$ (from table)

i.e $\left.X^{2} t=(r-1) X-1\right)$

$(2-1)(2-1)$

$=1$ i.e 3.84 with $50 \%$ degree of freedom.

Analysis: Since $X^{2} C>X^{2}$ (i.e. 52.6> 3.84) then the null hypothesis is rejected and $\mathrm{H}_{1}$ hypothesis is accepted. The implication of this is that poor economic opportunities and lack of infrastructural facilities in the area caused ruralurban migration, for instance, in Ibarapa East Local Government; there are a few industries that can create employment opportunities for the people.

Likewise, infrastructural facilities are poor comparing with other local government areas in the city. E.g Ibadan. There is no pipe borne water, no telephone services and postal services, electricity is not regularly supplied and health care is also poor, so, people have to migrate to urban areas to look for employment opportunities because of the presence of industries and good infrastructural in the town or city.

\section{Hypothesis II}

Ho: unavailability of standard secondary and higher institution rural areas of Ibarapa East Local Government increases the rate of rural-urban migration.

$\mathrm{H}_{1}$ : unavailability of standard secondary and higher institution rural areas of Ibarapa East Local Government increases the rate f rural-urban migration.

Table 2

\begin{tabular}{|l|c|c|c|}
\hline & YES & NO & \\
\hline Male & $48(98.19 \%)$ & $3(59 \%)$ & $51(100 \%)$ \\
\hline Female & $27(90 \%)$ & $3(10 \%)$ & $30(100 \%)$ \\
\hline Total & 76 & 6 & 81 \\
\hline
\end{tabular}

\begin{tabular}{|l|c|c|c|c|c|}
\hline Option & Fo & Fe & Fo-Fe & $(\mathrm{Fo}-\mathrm{Fe})^{2}$ & $(\mathrm{Fo}-\mathrm{Fe})^{2} / \mathrm{Fe}$ \\
\hline Yes & 75 & 40.5 & 34.5 & $1,190.25$ & 29.39 \\
\hline No & 6 & 40.5 & 34.5 & $1,190.25$ & 29.39 \\
\hline Total & & & & & 58.78 \\
\hline
\end{tabular}

The computed $\mathrm{X}^{2} \mathrm{C}=58.78$

At ${ }^{\prime} 5 \%$ level of significance the $X^{2}=3.84$

Analysis: since $X^{2} C>X^{2}$ (i.e $58.78>3.84$ ), then the null hypothesis is rejected and Hi hypothesis is accepted. This implies that unavailability of standard secondary and higher institution in rural areas of (lbarapa East Local Government) increase the rate of rural-urban migration. The result is but stressed by the fact that there are 36 secondary schools in Ibarapa East Local Government but villages and towns fall between the territory of Ibarapa East Local Government. Five of them were visited by the researcher and it was observed that majority of the secondary schools in the area do not have a standard library, since laboratory, even some do not have adequate and good classrooms. Also, there is only one higher institution in Ibarapa East Local Government and many of the parents thought that the greatest gift and legacy they could give their children is the best and standard education. As a result they move from one town under Ibarapa East Local Government Area e.g. Lanlate and Eruwa towns to urban cities like Lagos and Ibadan where there are secondary school and higher institution from their children to attend.

\section{Hypothesis III}

$\mathrm{H}_{\mathrm{o}}$ : Rural-urban migrationdo not have any effect on educational development in Ibarapa east Local Government.

$\mathrm{H}_{1}$ : Rural-urban migration has any effect on educational development in Ibarapa East Local Government.

Table 3

\begin{tabular}{|l|c|c|c|}
\hline & YES & NO & \\
\hline Male & $12(23.08 \%)$ & $40(76.9 \%)$ & $52(100 \%)$ \\
\hline Female & $8(26.7 \%)$ & $22(73.3 \%)$ & $30(100 \%)$ \\
\hline Total & 20 & 62 & 81 \\
\hline
\end{tabular}

\begin{tabular}{|l|c|c|c|c|c|}
\hline Option & Fo & Fe & Fo-Fe & $(\mathrm{Fo}-\mathrm{Fe})^{2}$ & $(\mathrm{Fo}-\mathrm{Fe})^{2} / \mathrm{Fe}$ \\
\hline Yes & 20 & 41 & 21 & 441 & 10.76 \\
\hline No & 612 & 41 & 21 & 441 & 10.76 \\
\hline Total & & & & & 21.52 \\
\hline
\end{tabular}

The computed $\mathrm{X}^{2} \mathrm{C}=21.52$

At $5 \%$ level of significance the $X^{2}=3.84$

Analysis: Since $X^{2}>X^{2}$ (i.e. $21.52>34$ ) then the null hypothesis is rejected and Hi hypothesis accepted. This implied that the movements of people from Ibarapa East Local Government to urban cities have effect on the educational development of the area.

\section{Hypothesis IV}

$H_{\circ}$ : Rural-urban migration does not contribute to the shortage of qualified teachers in Ibarapa East local Government.

$\mathrm{H}_{1}$ : Rural-urban migration contributes to the shortage of qualified teachers' kin Ibarapa East Local Government.

Table 4

\begin{tabular}{|l|c|c|c|}
\hline & YES & NO & \\
\hline Male & $10(19.2 \%)$ & $42(80.8 \%)$ & $52(100 \%)$ \\
\hline Female & $5(16.7 \%)$ & $25(63.3 \%)$ & $30(100 \%)$ \\
\hline Total & 15 & 67 & \\
\hline
\end{tabular}

\begin{tabular}{|l|c|c|c|c|c|}
\hline Option & Fo & Fe & Fo-Fe & $(\mathrm{Fo}-\mathrm{Fe})^{2}$ & $(\mathrm{Fo}-\mathrm{Fe})^{2} / \mathrm{Fe}$ \\
\hline Yes & 15 & 41 & 26 & 676 & 16.49 \\
\hline No & 67 & 41 & 26 & 676 & 32.98 \\
\hline Total & & & & & 32.98 \\
\hline
\end{tabular}

The computed $\mathrm{X}^{2} \mathrm{C}=32.98$

At $5 \%$ level of significance the $X^{2}=3.84$

Analysis: Sine $X^{2} C>X^{2}$ (i.e $32.98>3.84$ )

Then the null hypothesis is rejected and alternative hypothesis accepted. The implication of this is that rural- 
urban migration contributed to the shortage and alternative of qualified teachers in Ibarapa East Local Government. This is as a result of large population or numbers of skilled or qualified teachers who might have migrated out thus, causing shortage fall in the number of qualified teachers especially in some key subjects like English language, Mathematics, Economics, Biology, Chemistry and so on, the study shows that there is only one English language teachers at Obaseeku High School, Eruwa and population in about 550 , this has been contributed to the poor performance of student in the subjects.

\section{Hypothesis V}

$H_{0}$ : Rural-urban migration does not cause short age of labour in the agricultural sector in Ibarapa East Local Government.

$\mathrm{H}_{1}$ : Rural-urban migration causes the shortage of labour in the agricultural sector in Ibarapa Local Government.

Table 5

\begin{tabular}{|l|c|c|c|}
\hline & YES & NO & \\
\hline Male & $46(88.5 \%)$ & $6(21.3 \%)$ & $52(100 \%)$ \\
\hline Female & $26(86 \%)$ & $4(23.3 \%)$ & $30(100 \%)$ \\
\hline Total & 72 & 10 & 82 \\
\hline
\end{tabular}

\begin{tabular}{|c|c|c|c|c|c|}
\hline Option & Fo & Fe & Fo-Fe & $(\text { Fo-Fe })^{2}$ & $(\mathrm{Fo}-\mathrm{Fe})^{2} / \mathrm{Fe}$ \\
\hline Yes & 72 & 41 & 31 & 96.1 & 24.44 \\
\hline No & 10 & 41 & 31 & 96.1 & 23.44 \\
\hline Total & & & & & 47.88 \\
\hline
\end{tabular}

The computed $\mathrm{X}^{2} \mathrm{C}=47.88$

At $5 \%$ level of significance the $X^{2}=3.84$

Analysis: Sine $X^{2} C>X^{2}=$ (i.e. 46.88>3.84) then the null hypothesis is rejected and alternative hypothesis. This implies that rural-urban migration cause shortage of labor in the agricultural sector in Ibarapa East Local Government.

\section{Hypothesis VI}

$\mathrm{H}_{\mathrm{o}}$ : The movement of people from rural areas to urban productivity in our country.

$\mathrm{H}_{1}$ : The movement of people from rural areas to urban center contributes to the low the agricultural productivity in our country.

Table 6

\begin{tabular}{|l|c|c|c|}
\hline & YES & NO & \\
\hline Male & $14(26.9 \%)$ & $28(73.1 \%)$ & $52(100 \%)$ \\
\hline Female & $11(36.7 \%)$ & $19(63.3 \%)$ & $30(100 \%)$ \\
\hline Total & 25 & 57 & 87 \\
\hline
\end{tabular}

\begin{tabular}{|l|c|c|c|c|c|}
\hline Option & Fo & Fe & Fo-Fe & $(\text { Fo-Fe })^{2}$ & $(\mathrm{Fo}-\mathrm{Fe})^{2} / \mathrm{Fe}$ \\
\hline Yes & 25 & 41 & 16 & 256 & 6.24 \\
\hline No & 57 & 41 & 16 & 256 & 6.24 \\
\hline Total & & & & & 12.48 \\
\hline
\end{tabular}

The computed $\mathrm{x}^{2} \mathrm{C}=12.48$

At $5 \%$ of significance the $X^{2} C>X^{2}=3.48$
Analysis: Since $X^{2} C>X^{2}$ (i.e. $12.48>3.48$ ) then the null hypothesis is rejected and alternative hypothesis accepted. This implies that that movement of people from the rural area to urban center contributes to the low the agricultural productivity in our country. The study shows that the people of Alapa, Okolo, Temidire, Owode, Ilado and other surrounding villages in Ibarapa East Local Government helped in the production and supplied the cities with Gari, Maize and other foods stuff. But due to the movement of people from these areas in urban cities, the production of the level has significantly dropped. The dropping in the production level of food drops often leads to the high price of food stuff in our country.

\section{Hypothesis VII}

$\mathrm{H}_{\mathrm{o}}$ : Rural-urban migration does not promote juvenile delinquency, crimes and other social vices in our society.

$\mathrm{H}_{1}$ : Rural-urban migration does not promote juvenile delinquency, crimes and other social vices in our society.

Table 7

\begin{tabular}{|l|c|c|c|}
\hline & YES & NO & \\
\hline Male & $50(96.2 \%)$ & $2(3.8 \%)$ & $52(100 \%)$ \\
\hline Female & $25(83.38)$ & $5(16.7 \%)$ & $30(100 \%)$ \\
\hline Total & 75 & 7 & 82 \\
\hline
\end{tabular}

\begin{tabular}{|l|c|c|c|c|c|}
\hline Option & Fo & Fe & Fo-Fe & $(\mathrm{Fo}-\mathrm{Fe})^{2}$ & $(\mathrm{Fo}-\mathrm{Fe})^{2} / \mathrm{Fe}$ \\
\hline Yes & 75 & 41 & 34 & 1156 & 282 \\
\hline No & 7 & 41 & 34 & 1156 & 282 \\
\hline Total & & & & & 56.4 \\
\hline
\end{tabular}

The computed $\mathrm{X}^{2} \mathrm{C}=56.4$

At $5 \%$ level of significance the $X^{2}=3.84$

Analysis: Since $\mathrm{X}^{2} \mathrm{C}>\mathrm{X}^{2}$ (i.e. $56.4>3.84$ ) then the null hypothesis is rejected and alternative hypothesis accepted. This means that rural-urban migration promotes juvenile delinquencies, crimes and social vices in our society. The result is bitterness by the fact that there are many criminally minded people in the urban cities who engaged in armed robbery, stealing and thuggery simply because they are unemployed in the societies.

\section{Hypothesis VIII}

$\mathrm{H}_{\mathrm{o}}$ : High rate of unemployed in our country is one of the consequences of rural-urban migration.

$\mathrm{H}_{1}$ : High rate of unemployed in our country is one of the consequences of rural-urban migration

Table 8

\begin{tabular}{|l|l|l|l|}
\hline & YES & NO & \\
\hline Male & $41(82 \%)$ & $9(18 \%)$ & $50(100 \%)$ \\
\hline Female & $22(72.3 \%)$ & $4(26.7 \%)$ & $30(100 \%)$ \\
\hline Total & 63 & 13 & 80 \\
\hline
\end{tabular}

The computed $\mathrm{X}^{2} \mathrm{C}=26.46$

At $5 \%$ level of significance the $X^{2}=3.84$ 
Analysis: Since $X^{2}>X^{2}$ (i.e. $26.46>3.84$ ) then the hypothesis is rejected while the alternative hypothesis is accepted. This implies that the high rate of unemployment in our country today as a result of rural-urban migration. The study revealed that there is a mass movement of people from rural to urban towns with the aims of getting to the cities they found that there is existed only a few vacancies. Thus, there is a problem of unemployment in the urban areas.

\section{Discussions}

The Chi-square method and percentage are used to analyze data. It was found that factors influencing for poor economic opportunity and unavailability of standard schools and higher institution in rural areas. Moreover, the patterns of movement as well types of internal migration were simultaneously examined. The effects are experienced in both the sources region and the destination region due to rural-urban migration. Among the effects on sources region includes: reduction in working population, low productivity shortage of qualified teachers; low standard of education to mention but a few, while the negative effect on the destination region include the following: unemployment, traffic congestion, high rate of juvenile delinquencies, crime and other social vices. It is concluded from the information that rural-urban migration was imposed immeasurable problems on the sources region (rural) and destination (urban).

The factors responsible for rural-urban migration are the poor economic opportunity, lack of infrastructural facilities, unavailability of standard secondary schools and higher institution in rural areas. The movement has drastically contributed to reducing working population, low productivity, and shortage of qualified teachers and low standard of education in Ibarapa East Local Government Areas. And also responsible for overpopulation, high rate of crimes unemployment etc being experienced in the destination region (urban).

From over analysis above, can be observed that the high rate of rural-urban migration in our society is as a result of poor economic opportunities, lack of infrastructural facilities and unavailability of standard secondary and high institution in rural areas.

Also, our analysis revealed that rural-urban migration has effect on education development of the areas of study. It also shows that the migration of qualified teachers and labor in the agricultural sector of the study area.

More so, we can reduce from our results that migration of people from rural areas led to the low agricultural productivity in our country. The result also shows that the high rate of unemployment in our country today is as a result of high rate of rural-urban migration and this promotes crimes and other social vices in our society.

Based on the findings stated above the following recommendations were made: Firstly, the government should try as much as possible to provide social and infrastructural amenities such as good roads networks, medical or health facilities, pipe borne water, regular supply of electricity and others for the dwellers. This will reduce the rate at which people migrate from rural areas to the urban center in seeking for employment of social facilities that are not present in rural areas.

Secondly, all primary and secondary schools in rural areas should be provided with all necessary facilities such as standard library books, science laboratory, workshops and others. Higher institutions should be established in the rural areas so that the rural dwellers will benefit from the government education development and this will work for education purpose.

Thirdly, Government should establish much agro-based processing in the rural areas to provide employment opportunity for the urban areas for the same region individual lastly, to complement government's effort, individual and communities in the rural areas should try to engage in some projects which will enable community development. Such projects like the building of community schools establishment of medical or health centre private basis. All the increase the rate of development and reduce exodus of people from rural areas to urban centers. If all this recommendations are not put into consideration areas will be reduced and rural areas will attain modern standard environment.

With the various youth programs it could be possible to reduce rural-urban migration, most especially when the young ones are exposed to sustainable livelihood activities that they could embark upon. Hence, life will be better and comfortable for both rural and urban dwellers.

\section{REFERENCES}

Abiodun O.J (2005) Rural-urban Migration and Socio-Economic Development in Ghana.

Alhasan, N. S. and Abdullahi, T. (2013). Revitalizing Technical Vocational Educational and Training for youth empowerment and sustainable development. Journal of Educational and Social Research, 3(4), 149-144.

Blair T.I. (2004) On the Harris-Todaro model with Inter-spectral Migration of Labour.

Bogre D.J and Burgess (2007) Economics and Social Dimensions of Rural-urban Migration in Pakistan: Results from a Recent Survey in the North West Pakistan.

Dwyer O.J (2004) Ideas on Rural Economic Development. The Lytgeson Jone Company, Germany.

Makinwa K.P (2002) Rural-urban Migration and Socioeconomic Mobility in Victorian Britain.

National Population Commission (2006): National Population Census for 2006 report on Oyo State and environs

Onwubiko K.B.C. (2002) Migration and Rural Economic Pols. The Bobbs Merrill Company.

Otite E, A. (2004) Rural-urban Migration, Urban Unemployment and Underemployment and Job-Search Activity in LDCS. Journal of Development Economics. 
Shittu, S. (2004) A key note Address delivered by Honorable Commissioner for Education, Science and Technology at a meeting with the Newly Appointed principals of Junior Secondary School in the state on Monday $9^{\text {th }}$ August, 2004 at Lagelu Grammar school Hall,Agugu, Ibadan, Nigeria. Pp 156.
Trade Economics/National Bureau of Statistics (2012). Nigeria Population [online]. Available: http:/ / www.tradingeconomics.com (April, 2013).

White P. (2000) Social- Economic Factor Associated with Urbanrural Migration in Nigeria.

$--0-$ 